\title{
Cadmium and arsenic levels in edible fishes, Oreochromis niloticus (Nile tilapia) and Ompok bimaculatus (butter catfish) from Padaviya Reservoir, Sri Lanka and human health risk assessment associated with their dietary exposure
}

\author{
KAWS Weerasekara ${ }^{1^{*}}$, A Pathiratne ${ }^{2}$ and HMP Kithsiri ${ }^{1}$ \\ ${ }^{1}$ Environmental Studies Division, National Aquatic Resources Research \& Development Agency, Crow Island, Colombo 15. \\ ${ }^{2}$ Department of Zoology and Environmental Management, Faculty of Science, University of Kelaniya, Kelaniya.
}

\begin{abstract}
Consumption of fish contaminated with toxic heavy metals is a threat to human health. Cadmium and arsenic are suspected as potential risk factors for chronic kidney disease of unknown aetiology $(\mathrm{CKDu})$, which is highly prevalent in agricultural settlements in dry zone districts of Sri Lanka causing a severe public health crisis. Objectives of this study were (i) to determine cadmium and arsenic levels in muscle, liver and kidney of two edible fishes (Nile tilapia and butter catfish) from the Padaviya reservoir located in the North Central Province, Sri Lanka where CKDu is highly prevalent and (ii) to assess the potential human health risks associated with the dietary exposure through edible muscle of these fishes. Cadmium and arsenic levels of the tissues in the two fish species were determined using inductively coupled plasma mass spectrometry. In both fish species, highest cadmium levels were found in kidney $(\mathrm{p}<0.05)$ whereas no significant tissue specific differences $(p>0.05)$ were evident for arsenic. In the edible muscle, the maximum detected cadmium level in Nile tilapia was $0.1 \mathrm{mg} / \mathrm{kg}$ in wet weight. However, cadmium levels in the muscle of all Butter catfish were $<0.05 \mathrm{mg} / \mathrm{kg}$. Arsenic levels in the muscle of all Nile tilapia and Butter catfish were $<0.05 \mathrm{mg} / \mathrm{kg}$. Cadmium contents in muscle of most fishes and arsenic contents in all fishes $(\mathrm{n}=60)$ were within the maximum permissible limits set by the international food standards regulatory authorities. Based on the estimated daily intake and target hazard quotients $(<1)$ for lifetime exposure, it is highly unlikely that cadmium and arsenic contents of the muscle meat of these fishes would pose human health risks to moderate level consumers.
\end{abstract}

Keywords: Chronic kidney disease, heavy metal, ICP-MS, North Central Province, Padaviya reservoir fish, risk assessment.

\section{INTRODUCTION}

Consumption of fish provides an important source of protein, polyunsaturated fatty acids and essential minerals which are associated with health benefits and normal growth. However, contamination of fish with toxic heavy metals can affect the nutritional and other beneficial effects of fish on human health (CastroGonzález \& Méndez-Armenta, 2008). Due to the high degree of toxic effects, some heavy metals and metalloids such as cadmium and arsenic have been ranked as priority metals that are of public health significance. Cadmium and arsenic are systemic toxicants that could induce multiple organ damage, even at lower levels of exposure (Tchounwou et al., 2012; Karri et al., 2016; Wise et al., 2017). Inorganic forms of arsenic in food appears to be more toxic than the organic arsenic forms (USEPA, 2000; Castro-González \& Méndez-Armenta, 2008; Varol \& Sünbül, 2018).

Chronic kidney disease of unknown aetiology $(\mathrm{CKDu})$ is an emerging health problem in some low-

* Corresponding author (shyamalikaww@nara.ac.lk; (10 https://orcid.org/0000-0003-0085-9221)

This article is published under the Creative Commons CC-BY-ND License (http://creativecommons.org/licenses/by-nd/4.0/). This license permits use, distribution and reproduction, commercial and non-commercial, provided that the original work is properly cited and is not changed in anyway. 
and middle-income countries, including Sri Lanka, El Salvador and Nicaragua (Weaver et al., 2015). Heavy metals, especially cadmium and arsenic are suspected as potential risk factors for CKDu (Jayatilake et al., 2013). Yet, involvement of these elements in the pathogenesis of CKDu in Sri Lanka is still questionable (Nanayakkara et al., 2019). CKDu is highly prevalent in agricultural settlements in the Dry Zone districts of Sri Lanka causing a severe public health crisis among rural communities (Bandara et al., 2008; Jayatilake et al., 2013). Heavy metal exposure through the dietary intake of water and food may play significant contribution. Reservoir fish is the main source of animal protein of the rural people living in the Dry Zone. These reservoirs could be contaminated with heavy metals due to excessive use of agrochemicals in the Dry Zone (Bandara et al., 2008). Heavy metals can accumulate in fish directly through contaminated water and indirectly via the food chain (Castro-González \& Méndez-Armenta, 2008). Several studies have reported heavy metal contaminations in reservoir fishes in the Dry Zone of Sri Lanka (Bandara et al., 2008; Allinson et al., 2009; Jayatilake et al., 2013; Jinadasa \& Edirisinghe., 2013; Wijesinghe et al., 2018). Some studies showed that the measured heavy metal contents in the edible parts of the fish samples did not exceed the maximum limit for human consumption according to the international guidelines (Allinson et al.,
2009; Jinadasa \& Edirisinghe., 2013). More recently, Wijesinghe et al. (2018) reported that $\mathrm{Pb}, \mathrm{Cd}, \mathrm{Cr}, \mathrm{Cu}$ and $\mathrm{Zn}$ contents detected in the head part of Oreochromis mossambicus, Oreochromis niloticus and Etroplus suratensis from Minneriya, Parakrama Samudraya and Kaudulla reservoirs were higher than the provisional tolerable weekly intake of these metals specified by the FAO/WHO. The objectives of the present study were to determine the cadmium and arsenic levels in muscle, liver and kidney tissues of two commonly consumed fish species, Oreochromis niloticus (Nile tilapia) and Ompok bimaculatus (Butter catfish) from Padaviya reservoir located in an area in Sri Lanka where CKDu is highly prevalent. The potential human health risks associated with the consumption of cadmium and arsenic contaminated fishes was also assessed using three approaches: comparison of metal levels with maximum permissible levels (MPL); comparison of estimated daily intake with reference doses; and estimation of target hazardous quotients for non-carcinogenic effects.

\section{METHODOLOGY}

\section{Site description}

Padaviya Reservoir (848'32.30" N; 8045'26.04" E; catchment area: $532.48 \mathrm{~km}^{2}$ ) is a perennial reservoir

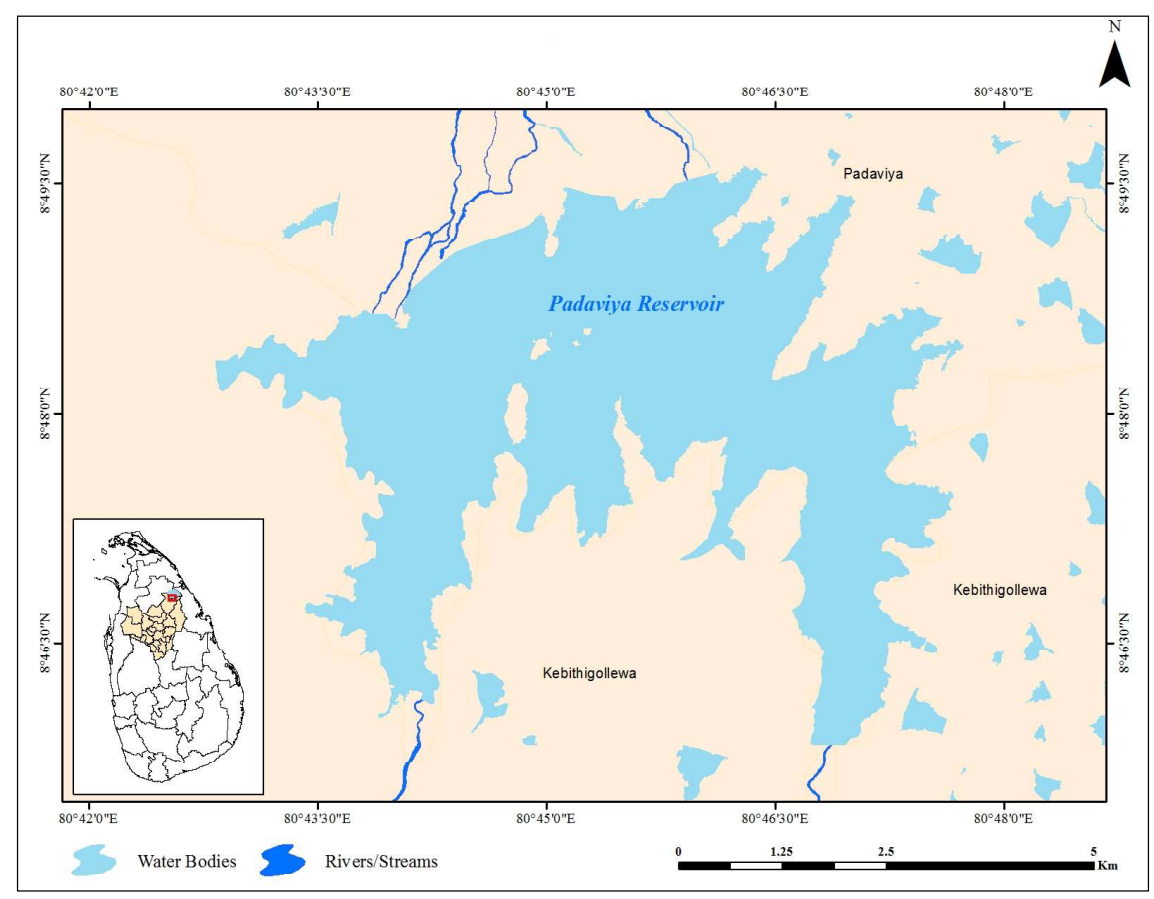

Figure 1: Location of Padaviya reservoir, Sri Lanka 
located in the Anuradhapura District in the North Central Province of Sri Lanka (Figure 1). Land uses in the area include forestry, paddy cultivation and other agricultural lands. The reservoir is fed by two seasonal streams, namely, Mukunu Oya and Mora Oya. It also receives rainwater during northeast monsoon period (Ministry of Irrigation and Water Resources Management, 2015). Fishery is an important economic activity that takes place in the reservoir. Nile tilapia and Butter catfish are two important edible freshwater fish species that mainly contribute to the inland fisheries sector.

\section{Sampling fish}

Freshly harvested samples of Nile tilapia (body weight: $180-300 \mathrm{~g}$; total length: $19-24 \mathrm{~cm}$ ) and Butter catfish (body weight: $110-225 \mathrm{~g}$; total length: $24-34 \mathrm{~cm}$ ) were randomly obtained from the fish landing sites of Padaviya reservoir in February, March and May 2018 covering a dry season where metals can be concentrated in the reservoir due to evapotranspiration. The fishes ( $n=10$ fish per each visit for each fish species) were transported to the laboratory in sealed freezer bags under ice cold storage conditions $\left(4^{\circ} \mathrm{C}-5^{\circ} \mathrm{C}\right)$. Upon arrival in the laboratory, body weight and total length of the fishes were measured. From each fish, muscle, liver and kidney tissues were obtained using stainless steel dissecting kits and frozen separately at $-20{ }^{\circ} \mathrm{C}$ until analysis.

\section{Analysis of metals}

Analysis of cadmium and arsenic in the fish tissues was carried out in the Industrial Technology Institute Colombo using Inductively Coupled Plasma Mass Spectrometry (ICP-MS). Briefly, homogenised wet tissue samples $(0.5-1.0 \mathrm{~g})$ were placed in digestion tubes containing $7.00 \mathrm{~mL}$ of concentrated nitric acid ( $\geq 69 \%$, AR grade) and $3.00 \mathrm{~mL}$ of $30 \%$ hydrogen peroxide. The samples were digested following the microwave digestion procedure for food in the CEM MARS 5 Microwave Digester (AOAC, 2012). The temperature was raised to $190{ }^{\circ} \mathrm{C}$ in $20 \mathrm{~min}$ and maintained for $20 \mathrm{~min}$ until the digestion was completed. The cooled digested solution was diluted to $25 \mathrm{~mL}$ with deionised water. Cadmium and arsenic levels in the samples were analysed using ICP-MS (Agilent 7900). Quality control and quality assurance aspects of the metal analyses included the use of analytical grade reagents for all analyses, use of calibration standards and certified reference materials. The correlation coefficients and regression coefficients of the calibration standards for the linear regression were above 0.995 and 99.7, respectively. Freeze-dried certified reference material (Dog fish liver; DOLT 04) from the National Research Council of Canada was used to validate the metal analysis following the same analytical procedure. Recovery of cadmium and arsenic levels in the certified reference material was around $78 \%$ and $91 \%$, respectively. Limit of Detection (LOD) was $0.05 \mathrm{mg} / \mathrm{kg}$ for both cadmium and arsenic.

\section{Human health risk assessment}

Potential human health risk associated with cadmium and arsenic through fish consumption was assessed using several approaches as described by Varol and Sünbül (2018). Firstly, heavy metal(loid) contents in fish samples were compared with the available maximum permissible levels (MPLs) of the respective metal(loid)s set by international food standards regulatory authorities (EC, 2006; FSANZ, 2013; MHPRC, 2013). Secondly, the estimated daily intake (EDI) of each heavy metal(loid), which depends on its concentration in edible fish parts (muscle meat) and the amount of fish consumption per day, was calculated and compared with reference dose (RfD) values reported by the USEPA (2000). The daily intake of metals from fish meals for adults was calculated using the following equation:

$\mathrm{EDI}=(\mathrm{MC} * \mathrm{IRd}) / \mathrm{BW}$

where, EDI is the estimated daily intake ( $\mathrm{mg} / \mathrm{kg}$ bw/day), $\mathrm{MC}$ is the metal concentration in fish muscle ( $\mathrm{mg} / \mathrm{kg}$ wet weight), IRd is the daily average fish ingestion rate $(\mathrm{kg} /$ day) and $\mathrm{BW}$ is the average body weight for an adult. In Sri Lankan context, the IRd for fish was taken as $0.060 \mathrm{~kg} /$ day (Allinson et al., 2009; 2010). Average body weight of an adult was considered as $70 \mathrm{~kg}$ (the USEPA default value). Considering the worst-case scenario, the maximum metal(loid) level detected in the edible muscle tissue was used as a more cautious approach for human health risk estimations. In cases where specific metal(loid) levels were below the LOD, LOD $/ \sqrt{2}$ was used (Verbovšek, 2011) as its concentration in the fish muscle for the risk estimations.

Thirdly, the target hazard quotient (THQ) was used to assess the non-carcinogenic human health risks associated with fish consumption as described by USEPA (2000) using equation (2). THQ is the ratio between the estimated dose of a contaminant and the respective RfD value. $\mathrm{RfD}$ is an estimate of a daily exposure to which the human population that may be exposed without an appreciable risk of deleterious effects during a lifetime. If the THQ $<1$, the exposed population is unlikely to experience obvious non-carcinogenic adverse effects. If the THQ $\geq 1$, there is a potential health risk (USEPA, 2000). 
$\mathrm{THQ}=\left[\left(\mathrm{EF}^{*} \mathrm{ED} * \mathrm{IRd} * \mathrm{MC}\right) /(\mathrm{RfD} * \mathrm{BW} * \mathrm{AT})\right]$

where, THQ is the target hazard quotient; $\mathrm{EF}$ is the exposure frequency (365 days/year); ED is the exposure duration (70 years); RfD is the oral reference dose ( $\mathrm{mg} / \mathrm{kg}$ body weight/day); AT is the averaging time for non-carcinogens $(365$ days/year $\times$ number of exposure years, assuming 70 years in this study). RfDs reported by USEPA (2000) for cadmium $(0.001 \mathrm{mg} / \mathrm{kg}$ body weight /day) and inorganic arsenic $(0.0003 \mathrm{mg} / \mathrm{kg}$ body weight /day) were used in the calculation. It was assumed that inorganic arsenic in the fish was $10 \%$ of the total arsenic content (Zhong et al., 2018).

For non-carcinogenic effects of metals, the maximum allowable daily fish consumption limits for adults $\left(\mathrm{CR}_{\lim }\right.$ in $\mathrm{kg} /$ day) were also estimated to determine the amount of fish that can be safely consumed daily using the following equation (USEPA, 2000):

$\mathrm{CR}_{\lim }=(\mathrm{RfD} * \mathrm{BW}) / \mathrm{MC}$

Maximum allowable daily consumption limits were converted to the number of allowable fish meals of a specified meal size per week using the following equation (USEPA, 2000).

$\mathrm{CR}_{\mathrm{mw}}=\left(\mathrm{CR}_{\text {lim }} * \mathrm{~T}_{\mathrm{ap}}\right) / \mathrm{MS}$

where, $\mathrm{CR}_{\mathrm{mw}}$ is the maximum allowable fish consumption rate per week (meals/week), $\mathrm{T}_{\text {ap }}$ is the time averaging period (7 days per week) and MS is the meal size ( $\mathrm{kg}$ fish $/$ meal). In this estimation, USEPA default value of $0.227 \mathrm{~kg}$ fish $/$ meal for adults was used as the meal size instead of $0.060 \mathrm{~kg}$ fish $/ \mathrm{meal}$, considering the high-end exposure groups due to heavy fish meal consumption.

\section{Statistical analysis}

All metal(loid) levels in fish are reported as wet tissue weight bases. For statistical interpretations, concentrations of the particular metal (loid), which were less than the LOD were estimated as $\mathrm{LOD} / \sqrt{2}$, as recommended by Verbovsek (2011). The same criterion was applied for risk assessment estimations when a particular metal(loid) level in all samples were below the LOD. Overall metal(loid) levels are presented as mean \pm SEM, median and the range (minimum and maximum) using descriptive statistics. For each fish, the measured metal(loid) levels in different tissues in different sampling events were compared separately by nonparametric Mann Whitney U test. The same statistical test was used for comparison of respective metal levels in the two fish species. Pearson's product moment correlation coefficient test was used to assess potential associations of metal(loid) levels in fish tissues with body weight and total length of the fishes. $p<0.05$ was considered as statistically significant. Statistical analysis was carried out using Minitab 17 statistical software package.

\section{RESULTS AND DISCUSSION}

\section{Cadmium and arsenic levels in fish tissues}

Cadmium levels in muscle, liver and kidney tissues of the two fish species are presented in Table 1. Cadmium contents in the muscle of majority of Nile tilapia were below the limit of detection $(<0.05 \mathrm{mg} / \mathrm{kg}$ wet weight $)$ whereas only five fish sampled in the third sampling event contained detectable amounts of cadmium in the muscle tissues (range $0.05-0.10 \mathrm{mg} / \mathrm{kg}$ ). Comparatively high levels of cadmium were found in the kidneys of Nile tilapia in the third sampling event (range $0.2-0.9 \mathrm{mg} / \mathrm{kg}$ ). Of the 30 Nile tilapia analysed in this study, livers of 10 fish and kidneys of 21 fish contained detectable levels of cadmium. In all Butter catfish $(n=30)$, cadmium content in the muscle was below the detection limit. However, the livers of 10 fish and kidneys of 20 fish contained detectable levels of cadmium. Comparatively high levels of cadmium were found in the kidney tissues of Butter catfish in the first and second sampling events (Table 1). In both fish species, the highest cadmium level was found in kidney tissues (Nile tilapia: $0.9 \mathrm{mg} / \mathrm{kg}$; Butter catfish $0.40 \mathrm{mg} / \mathrm{kg}$ ) in comparison to the muscle and liver tissues. In both fish species, overall cadmium levels in kidney tissues were significantly higher than that of the other tissues $(p<0.05)$. However, no significant differences $(p>0.05)$ were found between the two fish species with respect to overall cadmium levels.

Arsenic levels in the muscle tissues of all Nile tilapia and Butter catfish (Table 2) were below the limit of detection $(<0.05 \mathrm{mg} / \mathrm{kg}$ wet weight). Of the total number of fish analysed ( $\mathrm{n}=30$ for each species), arsenic was detected only in liver tissues of five Nile tilapia and one butter catfish, and kidney tissues in three Nile tilapia (Table 2). The highest arsenic level was found in kidney tissues $(0.46 \mathrm{mg} / \mathrm{kg})$ of Nile tilapia. In Butter catfish, the detected highest arsenic level was in liver tissue $(0.06$ $\mathrm{mg} / \mathrm{kg}$ ). For arsenic, no significant differences $(\mathrm{p}>0.05)$ in tissue specific or species specific bioaccumulative patterns were found.

Bioaccumulation of heavy metals in fishes may be related to various biological factors such as species, 
Table 1: Cadmium concentration in different tissues of Nile tilapia and butter catfish from Padaviya reservoir, Sri Lanka

\begin{tabular}{lccc}
\hline Fish and sampling event & \multicolumn{2}{c}{ Cadmium concentration $(\mathrm{mg} / \mathrm{kg}$ wet weight $)$} \\
& Muscle & Liver & Kidney \\
\hline Nile tilapia & $<0.05(0 / 10)$ & $<0.05-0.1(5 / 10)$ & $<0.05-0.15(6 / 10)$ \\
February 2018 & $<0.05(0 / 10)$ & $<0.05-0.14(4 / 10)$ & $<0.05-0.14(5 / 10)$ \\
March 2018 & $<0.05-0.1(5 / 10)$ & $<0.05-0.1(1 / 10)$ & $0.2-0.9(10 / 10)$ \\
May 2018 & $<0.05$ & $0.052 \pm 0.006$ & $0.185 \pm 0.039$ \\
Overall mean \pm SEM & $<0.05(<0.05-0.1)$ & $<0.05(<0.05-0.14)$ & $0.08(<0.05-0.9)^{*}$ \\
Overall median and range & $<0.05(0 / 10)$ & $<0.05-0.14(7 / 10)$ & $0.1-0.40(10 / 10)$ \\
Butter catfish & $<0.05(0 / 10)$ & $<0.05-0.07(3 / 10)$ & $0.13-0.35(10 / 10)$ \\
February 2018 & $<0.05(0 / 10)$ & $<0.05(0 / 10)$ & $<0.05(0 / 10)$ \\
March 2018 & $<0.05$ & $<0.05$ & $0.164 \pm 0.021$ \\
May 2018 & $<0.05(0 / 30)$ & $<0.05(<0.05-0.14)$ & $0.155(<0.05-0.40)^{*}$ \\
Overall mean \pm SEM & & & \\
Overall median and range & & & \\
\hline
\end{tabular}

Limit of detection of cadmium is $0.05 \mathrm{mg} / \mathrm{kg}$ wet weight. Sampling event-specific results are presented as minimum and maximum values; the numbers in parantheses indicate the ratio of fish with analysed metal above the detection limits to the total number of fish analysed in each sampling event $(n=10$ fish). No significant differences $(p>0.05)$ were found between the two species with respect to tissue specific overall cadmium levels. * Significantly different from muscle and liver $(\mathrm{p}<0.05)$

Table 2: Arsenic concentration in different tissues of Nile tilapia and Butter catfish from Padaviya reservoir, Sri Lanka

\begin{tabular}{lccc}
\hline Fish and Sampling event & \multicolumn{2}{c}{ Arsenic concentration $(\mathrm{mg} / \mathrm{kg}$ wet weight $)$} \\
& Muscle & Liver & Kidney \\
\hline Nile tilapia & $<0.05(0 / 10)$ & $<0.05-0.06(2 / 10)$ & $<0.05-0.46(1 / 10)$ \\
February 2018 & $<0.05(0 / 10)$ & $<0.05-0.06(1 / 10)$ & $<0.05(0 / 10)$ \\
March 2018 & $<0.05(0 / 10)$ & $<0.05-0.1(2 / 10)$ & $<0.05-0.09(2 / 10)$ \\
May 2018 & $<0.05$ & $<0.05$ & $0.053 \pm 0.014$ \\
Overall mean \pm SEM & $<0.05(0 / 30)$ & $<0.05(<0.05-0.1)$ & $<0.05(<0.05-0.46)$ \\
Overall median and range & $<0.05(0 / 10)$ & $<0.05-0.06(1 / 10)$ & \\
& $<0.05(0 / 10)$ & $<0.05(0 / 10)$ & $<0.05(0 / 10)$ \\
Butter catfish & $<0.05(0 / 10)$ & $<0.05(0 / 10)$ & $<0.05(0 / 10)$ \\
February 2018 & $<0.05$ & $<0.05$ & $<0.05(0 / 10)$ \\
March 2018 & $<0.05(0 / 30)$ & $<0.05(<0.05-0.06)$ & $<0.05$ \\
May 2018 & & & $<0.05(0 / 30)$ \\
Overall mean \pm SEM & & & \\
Overallmedian and range & $<$ & & \\
\hline
\end{tabular}

Limit of detection of arsenic is $0.05 \mathrm{mg} / \mathrm{kg}$ wet weight. Sampling event-specific results are presented only as minimum and maximum ranges: the numbers in parantheses indicate the ratio of fish with analysed metalloid above detection limits to the total number of fish analysed for each sampling event $(\mathrm{n}=10 \mathrm{fish})$. No significant differences in the arsenic levels were found among different tissues or the two species $(\mathrm{p}>0.05)$.

trophic status and tissue type (Andres et al., 2000; Castro-González \& Méndez-Armenta, 2008). In the present study, no species-specific significant differences were found with respect to the cadmium and arsenic levels between the two fish species caught from Padaviya reservoir. This can be attributed to the omnivorous feeding habit of both fish species. Nile tilapia (O. niloticus) feeds on phytoplankton, zooplankton, detritus and 
invertebrates whereas Butter catfish (O. bimaculatus) feeds on plant matter and fishes (www.fishbase.se). In general, concentrations of cadmium in the three tissues of both fish species followed the order: muscle $\approx$ liver $<$ kidney showing greater affinity of the kidney for cadmium bioaccumulation. In both fish species, the mean concentration of cadmium in the kidney was nearly five times greater than that in the muscle. Compared to other tissues, high levels of cadmium were also found in kidneys of some freshwater fish species caught from the Lot River, France (Andres et al., 2000). The results suggest that kidney is the main site of cadmium accumulation in fish. Arsenic levels in both species of fish were below the detection limits in most cases and did not show significant tissue-specific differences $(\mathrm{p}>0.05)$. A consistent tissue-specific arsenic accumulation pattern was also not evident with respect to arsenic levels in muscle, liver, intestine and gills of ten freshwater fish species caught from the Manchar Lake, Pakistan (Shah et al., 2009).

Table 3: Pearson correlations ( $r$ ) and significance ( $p$ ) of the associations between body weight and length and cadmium or arsenic contents in the tissues of Nile tilapia and Butter catfish

\begin{tabular}{|c|c|c|c|c|c|c|}
\hline \multirow[t]{2}{*}{ Metal(loid) } & \multirow[t]{2}{*}{ Fish } & \multirow[t]{2}{*}{ Tissue } & \multicolumn{2}{|c|}{$\begin{array}{l}\text { Body weight and } \\
\text { metal(loid) content }\end{array}$} & \multicolumn{2}{|c|}{$\begin{array}{l}\text { Total length and } \\
\text { metal(loid) content }\end{array}$} \\
\hline & & & $\mathrm{r}$ & $\mathrm{p}$ & $r$ & $\mathrm{p}$ \\
\hline \multirow[t]{6}{*}{ Cadmium } & Nile tilapia & muscle & -0.123 & 0.518 & -0.264 & 0.159 \\
\hline & & liver & 0.125 & 0.511 & 0.513 & 0.004 \\
\hline & & kidney & -0.041 & 0.831 & -0.006 & 0.973 \\
\hline & Butter catfish & muscle* & - & - & - & - \\
\hline & & liver & 0.282 & 0.131 & 0.121 & 0.525 \\
\hline & & kidney & 0.028 & 0.884 & -0.174 & 0.358 \\
\hline \multirow[t]{6}{*}{ Arsenic } & Nile tilapia & muscle* & - & - & - & - \\
\hline & & liver & 0.213 & 0.259 & 0.211 & 0.264 \\
\hline & & kidney & 0.221 & 0.242 & 0.097 & 0.610 \\
\hline & Butter catfish & muscle* & - & - & - & - \\
\hline & & liver & 0.120 & 0.529 & -0.237 & 0.206 \\
\hline & & kidney* & - & - & - & - \\
\hline
\end{tabular}

Body sizes (mean \pm sem and range): Nile tilapia, body weight $236 \pm 8(180-300) \mathrm{g}$ and total length $21.3 \pm 0.3(19-24) \mathrm{cm}$; Butter catfish, body weight $168 \pm 7(110-225) \mathrm{g}$ and total length $28.5 \pm 0.4(24-34) \mathrm{cm} . \mathrm{n}=30$ fish per species; degrees of freedom $=28$

*When all samples have the same value for a respective metal(loid) in the tissue, $r$ value could not be estimated.

Both fish species used in the study were within the edible size range (Table 3). Of the cadmium and arsenic levels in the three tissues of Nile tilapia and Butter catfish tested, the cadmium contents in the liver of Nile tilapia showed statistically significant positive correlations with the total length of the fish $(\mathrm{p}=0.004)$. No other statistically significant relationships were found between fish body size and cadmium or arsenic levels in the analysed fishes (Table 3). The results may indicate that cadmium accumulation capacity in the liver of Nile tilapia may increase as the fish gets longer with age. As cadmium can induce increased metallothionein production in Nile tilapia liver (Chandrasekera et al., 2008) bioaccumulation of cadmium in liver tissues may be increased with prolong exposure. Indrajith et al. (2008) reported strong positive correlations between body size (body weight and body length) and cadmium levels in the muscles of two estuarine food fishes, Etroplus suratensis and Ambassis comersoni from the Negombo estuary, Sri Lanka indicating high health risks associated with the consumption of bigger size fishes.

Limited scientific information is available on the levels of toxic metals in reservoir fishes in Sri Lanka. Most of the available studies have focused on metal levels in tilapia species. Allinson et al. (2009) reported 
that cadmium levels in the muscle of tilapia captured in 2002 from three reservoirs of Sri Lanka (Kaudulla, Rajanganaya, and Udawalawe reservoirs) ranged from $<0.15$ to $0.2 \mathrm{mg} / \mathrm{kg}$. Bandara et al. (2008) reported that mean levels of cadmium in the edible muscle of Nile tilapia captured from two reservoirs in the North Central Province, Sri Lanka ranged from 0.057 to 0.202 $\mathrm{mg} / \mathrm{kg}$. The highest cadmium levels detected in Nile tilapia from these two reservoirs were $0.115 \mathrm{mg} / \mathrm{kg}$ (Karapikkada reservoir) and $0.425 \mathrm{mg} / \mathrm{kg}$ (Thuruwila reservoir). Previously reported cadmium levels in tilapia from other reservoirs were higher than the levels found in muscles of Nile tilapia captured in 2018 from the Padaviya reservoir. Mean cadmium level in muscles of tilapia (Oreochromis sp.) collected in 2010 from selected reservoirs from the North Central, Southern and Eastern Provinces in Sri Lanka was $0.03 \mathrm{mg} / \mathrm{kg}$ on a dry weight basis (Jinadasa \& Edirisinghe, 2013), which would be much lower when converted to wet weight basis. Nevertheless, the reported mean level of cadmium in muscle of tilapia (Jinadasa \& Edirisinghe, 2013) is somewhat comparable to the levels of cadmium found in the two fish species analysed in the present study.

In this study, arsenic content in the edible muscle tissues of the two fish species was less than $0.05 \mathrm{mg} / \mathrm{kg}$ (estimated mean $0.035 \mathrm{mg} / \mathrm{kg}$ ). Reliable scientific reports on arsenic levels in the reservoir fish species in Sri Lanka are not available for comparison with the data in the present study. When compared with the recently reported arsenic levels in muscle tissues (wet weight basis) of freshwater fishes in other regions, the highest arsenic concentrations detected in Nile tilapia $(0.46 \mathrm{mg} / \mathrm{kg}$ in kidney) and Butter catfish $(0.06 \mathrm{mg} / \mathrm{kg}$ in liver) in this study were much lower than the mean arsenic levels reported in the muscle of Cyprinus carpio from Kabul River $(0.86 \mathrm{mg} / \mathrm{kg})$ and Chenab River $(2.98 \mathrm{mg} / \mathrm{kg})$ and Labeo rohita from upper Indus and lower Indus River ( 0.67 and $2.5 \mathrm{mg} / \mathrm{kg}$ respectively) in Pakistan (Nawab et al., 2018) and of Cyprinus carpio $(0.0759 \mathrm{mg} / \mathrm{kg})$ and Euphrates barbell $(0.132 \mathrm{mg} / \mathrm{kg})$ from Keban Dam Reservoir in Turkey (Varol \& Sünbül, 2018).

\section{Human health risk assessment}

Consumption of fish contaminated with toxic heavy metals is a threat to human health (Castro-González \& Méndez-Armenta, 2008). Heavy metals, especially cadmium and arsenic are suspected to be potential risk factors for $\mathrm{CKDu}$, which is highly prevalent in agricultural settlements in the Dry Zone districts of Sri Lanka and has posed a severe public health crisis among rural communities in recent times (Jayatilake et al.,
2013). The most likely avenue of metal exposure for these rural communities would be through the dietary intake of food and water (Bandara et al., 2008; Jayatilake et al., 2013). Reservoir fishes including Nile tilapia and Butter catfish are the main sources of animal protein of the rural people living in the Dry Zone districts of Sri Lanka. In this study, potential human health risks associated with dietary intake of cadmium and arsenic levels through Nile tilapia and Butter catfish from the Padaviya reservoir were assessed using three approaches: comparison of metal levels with maximum permissible levels (MPL); comparison of estimated daily intake with reference doses; and estimation of target hazardous quotients for non-carcinogenic effects as described by Varol and Sünbül (2018). Maximum permissible levels for heavy metal(loids) in fish for consumption of the general public have not yet been established by the food regulatory authorities in Sri Lanka. However, there is a gazette notification with respect to maximum levels of cadmium, lead and mercury in fish for export, which states that the maximum level of cadmium in export fish should be 0.05 $\mathrm{mg} / \mathrm{kg}$ wet weight (GOSL, 2007) which is similar to the MPL of cadmium $(0.05 \mathrm{mg} / \mathrm{kg}$ wet weight $)$ for muscle meat of fishes specified by the European Commission for human consumption (EC, 2006). Previous studies indicate that cadmium levels in the edible tissues of tilapia captured from some other reservoirs of Sri Lanka (Allinson et al., 2009; Jinadasa \& Edirisinghe, 2013) were within the acceptable international food regulatory limits for human consumption. In the edible muscles of Nile tilapia, the detected highest concentration of cadmium was $0.1 \mathrm{mg} / \mathrm{kg}$ whereas in all Butter catfish, cadmium concentrations in the muscles were below 0.05 $\mathrm{mg} / \mathrm{kg}$ (Table 1). When compared with the specified MPL for cadmium (Table 4), cadmium content in the edible muscle has exceeded in $3 \%$ of Nile tilapia, while cadmium contents in the muscle of all Butter catfish were below the respective MPL. Yet, cadmium contents in the kidney (53\% of Nile tilapia and $67 \%$ of Butter catfish) and liver (23\% Nile tilapia and $20 \%$ Butter catfish) tissues of a considerable portion of the sampled fish have exceeded the MPL for cadmium (Table 4). The MPL for total arsenic in fish has not been provided by most food standards of international regulatory authorities. The MPL for inorganic arsenic in fish for human consumption has been reported as $2 \mathrm{mg} / \mathrm{kg}$ wet weight by food regulatory authorities in Australia and New Zealand (FSANZ, 2013) while the Ministry of Health of the People's Republic of China has lowered the MPL value for inorganic arsenic in fish to $0.1 \mathrm{mg} / \mathrm{kg}$ wet weight (MHPRC, 2013). In the present study, even the total arsenic levels in three tissues of Nile tilapia 
and Butter catfish were below these inorganic arsenic MPL for human consumption (Table 4). When using the assumption that a $0.06 \mathrm{~kg}$ portion is consumed each day (Allinson et al., 2009), estimated daily intake values of cadmium and arsenic (Table 4) from Nile tilapia and Butter catfish muscle meat are several folds lower than the corresponding reference doses reported by the USEPA (2000) for edible portions of fish, indicating low health risks associated with the fish consumption. Target hazardous quotient values estimated for the respective metal(loid)s at this daily fish consumption rate (Table 4) are distinctively much lower than the hazard quotient threshold value of one (01) indicating low noncarcinogenic health risks associated with the cadmium and arsenic levels in muscle meat of these fishes.

Based on estimated consumption limits (Table 4), large quantities of Nile tilapia muscle tissue would need to be consumed daily on a regular basis to exceed the intake limits of cadmium $(>0.7 \mathrm{~kg})$ and inorganic arsenic $(>6 \mathrm{~kg})$ to pose non-carcinogenic health risks. Similarly, daily consumption of muscle tissue of Butter catfish should be greater than $2 \mathrm{~kg} /$ day and $6 \mathrm{~kg} / \mathrm{day}$, respectively to exceed the intake limits of cadmium and inorganic arsenic. Estimated maximum allowable fish consumption rates per week (meals/week) also indicate extremely heavy consumption conditions. These fish intake levels are considered highly unlikely for general population who consume fish at moderate levels.

In the human health risk assessment, it was assumed that cooking has no effect on cadmium and inorganic arsenic content in the muscle tissue portions and ingested dose is equal to the absorbed heavy metal dose. There is a possibility to ingest more cadmium if the kidney and liver tissues of the fishes are consumed as they showed greater cadmium accumulative capacities. The kidney of fishes may not be removed before cooking as it is firmly attached to the ventral part of the vertebral column of the fish. It is advisable to remove all liver and kidney tissues when preparing these fish for food. Cadmium and inorganic arsenic are classified as human carcinogens (Tchounwou et al., 2012; Wise et al., 2017). Hence, carcinogenic health risks associated with cadmium and arsenic exposure through these fishes cannot be excluded from the study. There can be synergistic or additive effects caused by exposure to low levels of multiple carcinogenic heavy metals from these fishes on human. Periodic monitoring of toxic metal and metalloid levels in reservoir fishes in areas where CKDu is highly

Table 4: $\quad$ Percentage exceeding maximum permissible levels (MPL); estimated daily intake (EDI); target hazardous quotient (THQ); maximum allowable daily fish consumption $\left(\mathrm{CR}_{\lim }\right)$ and number of allowable daily fish meals per week $\left(\mathrm{CR}_{\mathrm{mw}}\right)$ for cadmium and arsenic intake from contaminated muscle meat of Nile tilapia and Butter catfish from the Padaviya reservoir, Sri Lanka.

\begin{tabular}{llcc}
\hline & Fish & Cadmium & Inorganic arsenic \\
\hline MPL (mg/kg wet weight) & - & $0.05^{a}$ & $0.1^{b} ; 2^{c}$ \\
MPL exceedance for muscle & Nile tilapia & $3 \%$ & $0 \%$ \\
& Butter catfish & $0 \%$ & $0 \%$ \\
MPL exceedance for kidney & Nile tilapia & $53 \%$ & $0 \%$ \\
& Butter catfish & $67 \%$ & $0 \%$ \\
MPL exceedance for liver & Nile tilapia & $23 \%$ & $0 \%$ \\
& Butter catfish & $20 \%$ & $0 \%$ \\
Reference dose ${ }^{d}(\mathrm{mg} / \mathrm{kg}$ bw/day) & - & $1 \times 10^{-3}$ & $3 \times 10^{-4}$ \\
EDI (mg/kg bw/day) & Nile tilapia & $9 \times 10^{-5}$ & $3 \times 10^{-6}$ \\
& Butter catfish & $3 \times 10^{-5}$ & $3 \times 10^{-6}$ \\
THQ & Nile tilapia & 0.09 & 0.01 \\
$\mathrm{CR}_{\text {lim }}(\mathrm{kg} / \mathrm{day})$ & Butter catfish & 0.03 & 0.01 \\
$\mathrm{CR}_{\mathrm{mw}}(\mathrm{meals} / \mathrm{week})$ & Nile tilapia & 0.7 & 6 \\
& Butter catfish & 2 & 6 \\
\hline
\end{tabular}

${ }^{a}$ EC (2006); ${ }^{b}$ MHPRC; ${ }^{c}$ FSANZ (2013); ${ }^{d}$ USEPA (2000) 
prevalent in Sri Lanka is recommended considering the need to ensure safety of fish food for the vulnerable rural communities.

\section{rONRI IISION}

This study generated new information on cadmium and arsenic levels in two of the mostly consumed reservoir fish species in the Padaviya reservoir, Sri Lanka and their suitability for human consumption. In both fish species, the highest cadmium levels were found in the kidney tissue showing greater cadmium bioaccumulative capacity in the kidney tissues. However, for arsenic, no significant tissue specific bioaccumulative pattern was found in these fishes. In the edible muscle, the highest cadmium level detected was $0.1 \mathrm{mg} / \mathrm{kg}$ and arsenic levels were $<0.05 \mathrm{mg} / \mathrm{kg}$ on wet weight basis. Human health risk assessment revealed that cadmium contents in edible muscle of most fishes and arsenic contents in all fishes were within the maximum permissible limits set by international food regulatory authorities. According to the estimated daily intake and target hazard quotients, it is highly unlikely that cadmium and arsenic contents of the muscle meat of these fishes from Padaviya Reservoir would pose non-carcinogenic human health risks to moderate level consumers. However, carcinogenic health risks associated with heavy metal(ioid) exposure via fish food cannot be excluded.

\section{Acknowledgement}

This work was supported by the National Aquatic Resources Research and Development Agency, Sri Lanka.

\section{REFERENCES}

Allinson G., Salzman S.A., Turoczy N., Nishikawa M., Amarasinghe U.S., Nirbadha K.G.S. \& De Silva S.S. (2009). Trace metal concentrations in Nile Tilapia (Oreochromis niloticus) in three catchments, Sri Lanka. Bulletin of Environmental Contamination and Toxicology 82: 389-394.

DOI: https://doi.org/10.1007/s00128-008-9580-9

Allinson G., Salzman S.A., Turoczy N., Nishikawa M., Amarasinghe U.S., Nirbadha K.G.S. \& De Silva S.S. (2010). Observations on metal concentrations in commercial landings of two species of tilapia (Oreochromis mossambicus and Oreochromis niloticus) from reservoirs in six river basins in Sri Lanka. Toxicological and Environmental Chemistry 92: 749-763.

DOI: https://doi.org/10.1080/02772240903049710

Andres S., Ribeyre F., Tourencq J-N. \& Boudou A.
(2000). Interspecific comparison of cadmium and zinc contamination in the organs of four fish species along a polymetallic pollution gradient (Lot River, France). Science of the Total Environment 248: 11-25.

DOI: https://doi.org/10.1016/S0048-9697(99)00477-5

Association of Analytical Communities International (AOAC) (2012). AOAC Official Method 999.10. Association of Analytical Communities International, USA.

Bandara J.M.R.S., Senevirathna D.M.A.N., Dasanayake D.M.R.S.B., Herath V., Bandara J.M.R.P., Abeysekara T. \& Rajapaksha K.H. (2008). Chronic renal failure among farm families in cascade irrigation systems in Sri Lanka associated with elevated dietary cadmium levels in rice and freshwater fish Tilapia. Environmental Geochemistry and Health 30: 465-478.

DOI: https://doi.org/10.1007/s10653-007-9129-6

Castro-Gonzalez M.I. \& Mendez-Armenta M. (2008). Heavy metals: implications associated to fish consumption. Environmental Toxicology and Pharmacology 26: 263-271. DOI: https://doi.org/10.1016/j.etap.2008.06.001

Chandrasekera L.W.H.U., Pathiratne A. \& Pathiratne K.A.S. (2008). Effects of water borne cadmium on biomarker enzymes and metallothioneins in Nile tilapia, Oreochromis niloticus. Journal of the National Science Foundation of Sri Lanka 36(4): 315-322.

DOI: https://doi.org/10.4038/jnsfsr.v36i4.270

European Commission (EC) (2006). Commission Regulation (EC) No $1881 / 2006$ of 19 December 2006. Setting maximum levels of certain contaminants in foodstuff. Official Journal of the European Union 364: 5-24.

FishBase. A Global Information System on Fishes. Available at https://www.fishbase.se/search.php, Accessed 2019 May 25.

Food Standards Australia and New Zealand (FSANZ) (2013). Australia New Zealand Food Standards Code, Standard 1.4.1, Contaminants and Natural Toxicants. Available at http://www.legislation.gov.au/Details/F2013C00140/, Accessed 25 May 2019.

Government of Sri Lanka (GOSL) (2007). Maximum limits for Lead $(\mathrm{Pb})$, Cadmium $(\mathrm{Cd})$ and Mercury $(\mathrm{Hg})$ in fish and fishery products (No: 1528/7). The Gazette of the Democratic Socialist Republic of Sri Lanka. The Department of Government Printing, Colombo.

Indrajith H.A.P., Pathiratne K.A.S. \& Pathiratne A. (2008). Heavy metal levels in two food fish species from Negombo estuary, Sri Lanka: relationship with the body size. Sri Lanka Journal of Aquatic Sciences 13: 63-81. DOI: https://doi.org/10.4038/sljas.v13i0.2207

Jayatilake N., Mendis S., Maheepala P. \& Mehta F.R. (2013). Chronic kidney disease of uncertain aetiology: prevalence and causative factors in a developing country. $B M C$ Nephrology 14: 180.

DOI: https://doi.org/10.1186/1471-2369-14-180

Jinadasa B.K.K.K. \& Edirisinghe E.M.R.K.B. (2013). Cadmium, lead and total mercury in Tilapia sp. in Sri Lankan reservoirs. Food Additives and Contaminants: Part B 7(2): 90-94.

DOI: https://doi.org/10.1080/19393210.2013.849761 
Karri V., Schuhmacher M. \& Kumar V. (2016). Heavy metals $(\mathrm{Pb}, \mathrm{Cd}, \mathrm{As}$ and $\mathrm{MeHg})$ as risk factors for cognitive dysfunction: a general review of metal mixture mechanism in brain. Environmental Toxicology and Pharmacology 48: 203-213.

DOI: https://doi.org/10.1016/j.etap.2016.09.016

Ministry of Health of the People's Republic of China (MHPRC) (2013). National Food Safety Standard, Maximum Levels of Contaminants in Foods (GB2762-2012). Ministry of Health of the People's Republic of China, China.

Ministry of Irrigation and Water Resources Management (2015). Dam Safety and Water Resources Planning Project, Sri Lanka. Ministry of Irrigation and Water Resources Management, Colombo 10.

Nanayakkara S., Senevirathna S.T.M.L.D., Harada K.H., Chandrajith R., Hitomi T., Abeysekera T., Muso E., Watanabe T. \& Koizumi A. (2019). Systematic evaluation of exposure to trace elements and minerals in patients with chronic kidney disease of uncertain etiology $(\mathrm{CKDu})$ in Sri Lanka. Journal of Trace Elements in Medicine and Biology 54: 206-213.

DOI: https://doi.org/10.1016/j.jtemb.2019.04.019

Nawab J., Khan S. \& Xiaoping W. (2018). Ecological and health risk assessment of potentially toxic elements in the major rivers of Pakistan: general population vs. fishermen. Chemosphere 202: 154-164.

DOI: https://doi.org/10.1016/j.chemosphere.2018.03.082

Shah A.Q., Kazi T.G., Arain M.B., Jamali M.K., Afridi H.I., Jalbani N., Baig J.A. \& Kandhro G.A. (2009). Accumulation of arsenic in different freshwater fish species - potential contribution to high arsenic intakes. Food Chemistry 112: 520-524.

DOI: https://doi.org/10.1016/j.foodchem.2008.05.095

Tchounwou P.B., Yedjou C.G., Patlolla A.K. \& Sutton D.J. (2012). Heavy metal toxicity and the environment. In: Molecular, Clinical and Environmental Toxicology (ed. A. Luch). Springer, Basel, Switzerland.
DOI: https://doi.org/10.1007/978-3-7643-8340-4_6

United States Environmental Protection Agency (USEPA) (2000). Guidance for Assessing Chemical Contaminant Data for Use in Fish Advisories, Volume II. Risk Assessment and Fish Consumption Limits. EPA 823-B-00-008. United States Environmental Protection Agency, Washington DC, USA.

Varol M. \& Sünbül M.R. (2018). Multiple approaches to assess human health risks from carcinogenic and non-carcinogenic metals via consumption of five fish species from a large reservoir in Turkey. Science of the Total Environment 633: 684-694.

DOI: https://doi.org/10.1016/j.scitotenv.2018.03.218

Verbovšek T. (2011). A comparison of parameters below the limit of detection in geochemical analyses by substitution methods. RMZ-Materials and Geoenvironment 58(4): 393404.

Weaver V.M., Fadrowski J.J. \& Jaar B.G. (2015). Global dimensions of chronic kidney disease of unknown etiology $(\mathrm{CKDu})$ : a modern era environmental and/or occupational nephropathy? BMC Nephrology 16: 145. DOI: https://doi.org/10.1186/s12882-015-0105-6

Wise J.T.F., Wang L, Zhang Z. \& Shi X. (2017). $9^{\text {th }}$ conference on metal toxicity and carcinogenesis: the conference overview. Toxicology and Applied Pharmacology 331: $1-5$.

DOI: https://doi.org/10.1016/j.taap.2017.04.007

Wijesinghe H., Idroos F.S. \& Manage P.M. (2018). Heavy metal contamination status in seven fish species from reservoirs of Polonnaruwa district, Sri Lanka. Sri Lanka Journal of Aquatic Sciences 23(1): 95-104. DOI: http://doi.org/10.4038/sljas.v23i1.7550

Zhong W., Zhang Y., Wu Z., Yang R., Chen X., Yang J. \& Zhu L. (2018). Health risk assessment of heavy metals in freshwater fish in the central and eastern North China. Ecotoxicology and Environmental Safety 157: 343-349. DOI: https://doi.org/10.1016/j.ecoenv.2018.03.048 